\title{
Budvicia aquatica
}

National Cancer Institute

\section{Source}

National Cancer Institute. Budvicia aquatica. NCI Thesaurus. Code C86221.

A species of facultatively anaerobic, Gram-negative, rod shaped bacteria assigned to the phylum Proteobacteria. This species is non-spore forming, non-encapsulated, oxidase and indole negative, catalase positive, reduces nitrates, hydrolyzes urea, but not esculin and is motile using a peritrichous flagella however, some strains can be nonmotile. B. aquatica is found in water and small mammals and is pathogenic to humans. 